\title{
Project NAD - Part 2: a marine geophysical project offshore East Greenland
}

\author{
Jørgen B. Risum
}

On 24th May 1979 the Council of the European Communities adopted its regulation No 1038/79 on Community support for a hydrocarbon exploration project in Greenland Project NAD. This project is an integrated aeromagnetic and marine geophysical project off the east coast of Greenland. Part 1 is the aeromagnetic programme - Project EASTMAR Larsen \& Thorning, this report); part 2 is the marine geophysical programme. The aim of this project is to map the continental margin of East Greenland, using high sensitivity aeromagnetic surveys and multichannel seismic reflection and marine gravity surveys, and to prepare a preliminary petroleum geological assessment of the region.

\section{Background}

Based on the evidence of both aeromagnetic and marine geophysical work done by various research organisations, sedimentary basins are known to exist offshore East Greenland (Larsen \& Thorning, 1979; Larsen, this report).

The data available from these investigations are of a rather varied quality. Most of the seismic data are shallow penetration data and the line-spacing is variable. The new project EASTMAR data will be a most valuable contribution to a detailed delineation of the sedimentary basins. However, to evaluate fully the basins and structures in the basins, a deep penetration seismic survey of commercial standard is needed. Only one of the previous surveys employed a multi-coverage seismic survey of a quality sufficiently high for this evaluation (Hinz \& Schlüter, 1978). From this survey only a few lines are available on the East Greenland shelf and a more closely spaced grid is needed. It is hoped that the project NAD - Part 2 will provide this.

\section{The marine acquisition programme}

Fig. 34 shows a tentative layout of the programme with a total of approximately 9000 line $\mathrm{km}$. It is hoped that it will be possible to carry this out during the three field seasons of 1980 , 1981 and 1982. However the polar pack ice offshore East Greenland may seriously interfere with the programme. The three year plan is designed to meet the average ice conditions during that period. August and September are considered to be the best months for operations in this area.

The data acquisition programme will consist of 48 -fold reflection seismic recording, marine gravity and magnetic recording, and sonobuoy refraction measurements. The vessel will have to be suitable for work in arctic waters and should have an ice classification. It is intended to carry a small helicopter onboard for ice reconnaissance in the vicinity of the vessel, and to employ satellite images and observations from aeroplanes for regional studies of the ice coverage. Positioning will be done using satellite navigation with doppler sonar and Loran $C$ integrated. The seismic energy source will be at least a 2000 cubic inch airgun 


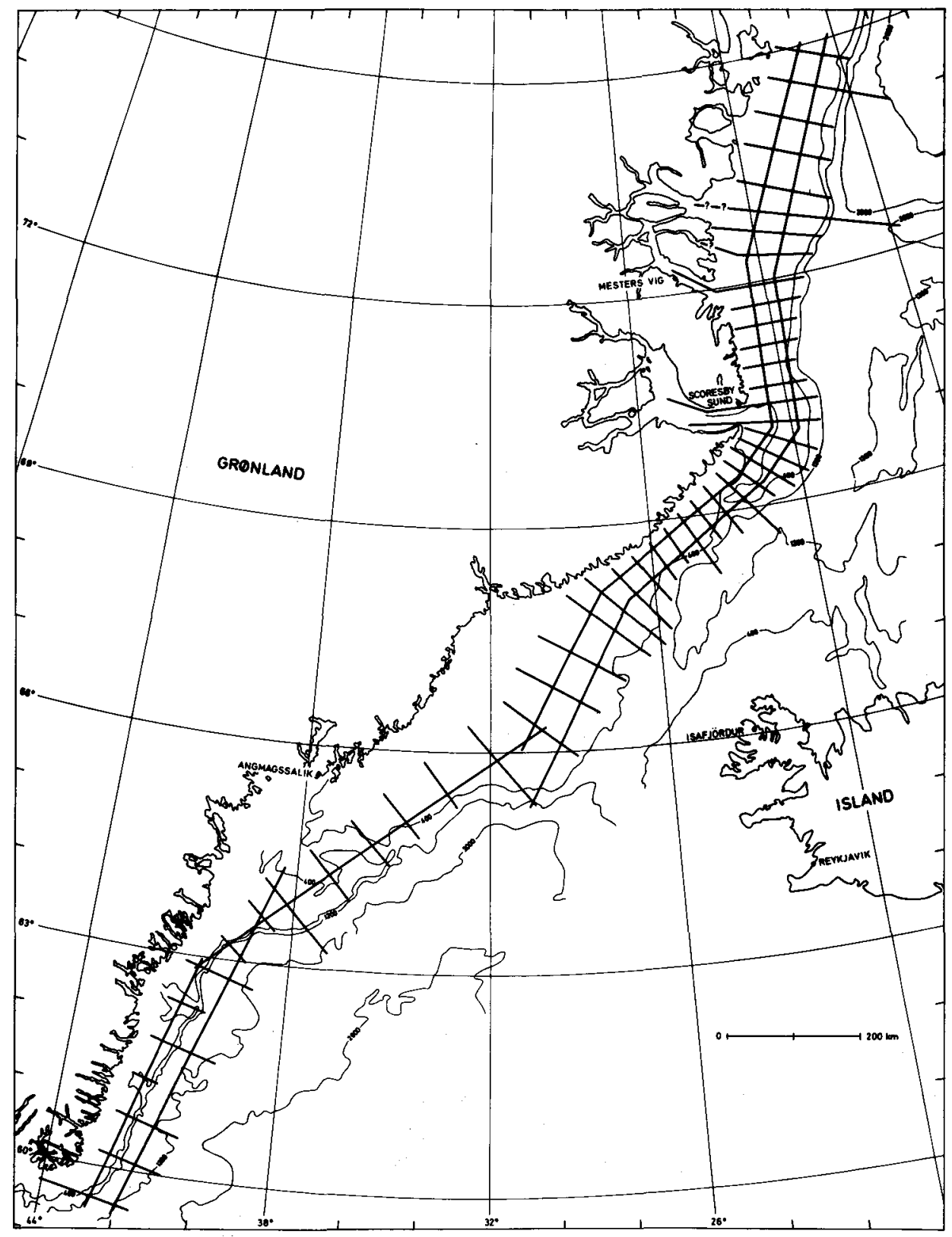

Fig. 34. Preliminary map of the planned survey grid. 
array or equivalent, and the cable will be a $2400 \mathrm{~m}, 48$ group streamer or equivalent. The configuration of the shooting geometry will be such that a 48 -fold CDP coverage can be achieved. The seismic work will be carried out by a seismic contractor.

\section{Data processing and interpretation}

The seismic data will be submitted for standard processing by a seismic data processing contractor. Certain lines may later be selected for special processing or migration.

All available data will be integrated in the interpretation. The aim will be to produce, depending on the area, contoured two-way travel time maps of the acoustic basement and of some of the sedimentary horizons. True depth maps will be produced as required, based on a study of the velocity data from both reflection and refraction seismic data. A study of seismic stratigraphy will be made and an attempt will be made to establish the stratigraphy of the offshore area on this basis.

Data on the ice, weather and sea state will be evaluated during the project to the extent that it is relevant to the current work and to decisions on the feasibility of future exploration activity in this area.

\section{References}

Hinz, K. \& Schlüter, H.-U. 1978: Der Nordatlantik - Ergebnisse geophysikalischer Untersuchungen der Bundesanstalt für Geowissenschaften und Rohstoffe an nordatlantischen Kontinentalrändern. Erdöl-Erdgas Z. 94, 271-280.

Larsen, H. C. \& Thorning, L. 1979: Project Eastmar: planning of an aeromagnetic survey off East Greenland. Rapp. Grønlands geol. Unders. 95, 93-96.

\section{Airborne remote sensing in East Greenland}

\section{Tage Thyrsted}

In the spring of 1979 a remote sensing project in East Greenland was commenced, introducing this new method of investigation to Greenland. The aim of the project is to investigate the possibility of using airborne remote sensing in connection with mineral exploration. In the region chosen for investigation (Inset, fig. 35) several mineralisations of different types and ages occur, and the purpose is to find out which remote sensing techniques and data processings are appropriate for detection and reproduction on images of these known mineralisations. The region is geologically well known and it is well exposed, vegetation and secondary cover being very limited.

The project is being carried out as a joint French-Danish operation between Groupement 